\title{
3-2 次世代テレビについて
}

\section{3-2-1 パーソナルテレビ}

\section{1. ま え がき1)}

近年, ページャ, PDA (Personal Digital Assistance) , 情報スーパーハイウエイ構想と, 我々の周り の高度情報化社会の成長には目まぐるしいものがあ る。人々が情報を収集する手段は，ラジオやテレビ， 新聞や雑誌などの従来の一方向のメディアから, パソ コン通信や PDA などの双方向通信機能を持ったメデ ィアへと多種多様化し, それぞれのメディアの特徴を 生かした情報収集をするようになってきた。また，パ ソコンでテレビを見たり, 音楽を聴くことも可能とな った。マルチメディア時代と呼ばれる情報汇濫社会に おいては，「いつでも，どこでも，だれでも」自分の 必要とする情報を得られるようにすることが求められ る。

従来のパーソナルテレビは, 地上波を受けて屋内外 でテレビ放送を見るか，カムコーダのようにテープな どのパッケージメディアと組合せて利用するのが一般 的で, いわば「モノメディアテレビ」であった。「ポ ータビリティの確保」というパーソナルユースの必要 条件の下で, マルチメディア時代のパーソナルテレビ が実現すべき要件を考え，急速に進歩している技術卜 レンドから, 近未来のパーソナルテレビの姿を描いて みたい。

\section{2. マルチメディアテレビの基本構成}

マルチメディアテレビは, 図 1 に示すように, 受信 者が必要としている情報を, 情報発信者から, 様々な 通信媒介者を介して, 受信者の状況に合わせて伝える 「橋渡し」の役割を果たす。

これを実現するハードウェアは，情報の送受信を行 う通信インタフェースと入出力操作を行うユーザイン タフェース, 様々な処理を行う演算部, 情報または設

$\dagger$ ソニー株式会社 中央研究所

“3-2 Next Generation Television Systems 3-2-1 Personal Television in Multimedia Era"by Masanobu Yamamoto (Research Center, Sony Corp., Tokyo)
正会員 山本 畺 伸 $^{\dagger}$

定などを保存する蓄積部, そして, 受信者に情報を伝 える表示部なら構成される。

情報発信者と受信者の関係を, 通信形態と内容から 分類すると表 1 亿示す 4 つが挙げられる.

マルチメディアテレビでは, 従来の放送 $(\mathrm{A})$ に加 え, 新聞や出版などを含む多種多様な一方向性情報 (B) の受信・表示をするのみならず，個人または少人 数間での双方向性情報 $(\mathrm{C}, \mathrm{D})$ の送受信・表示をも行 う.

ここでパーソナルテレビがパソコンや据置型マルチ メディアテレビと異なる点は, 通信拉よびユーザイン タフェース機能である. 通信機能は送信よりも受信 を, ユーザインタフェース機能は入力（キーボードな ど)よりも出力(表示)に主眼をおいていることである. したがって, パーソナルテレビは表示機能と携帯性を 特徵とし, 特に, 携帯型情報端末との差異は表示機能 にある。

\section{3. パーソナルテレビの要求仕様}

パーソナルテレビの使用法は大きく分けて 3 つあ る.第一に，カバンなどに入れて持ち歩くハンディテ レビ、第二に, カーナビゲーションのように移動体に 搭載するモービルテレビ. 第三に, 家庭やオフィス内 で持ち運べるポータブルテレビである。これらタイプ の違いにより, 大きさ, 消費電力といった仕様に差異 が生じてくる(表 2 ).

携帯性を考慮すると, ハンディテレビでは片手に馴

表 1 情報伝達の種類と分類
A. ブロードキャスト・一方向・実時間
‥ラジオ放送, テレビ放送
B. ブロードキャスト・一方向・時間差
…新聞, 出版, パッケージメディア
C. コミュニケート・双方向・実時間
‥電話, テレビ電話, 無線電話
D. コミュニケート・双方向・時間差
‥郵便, 電子メール, 宅配便 


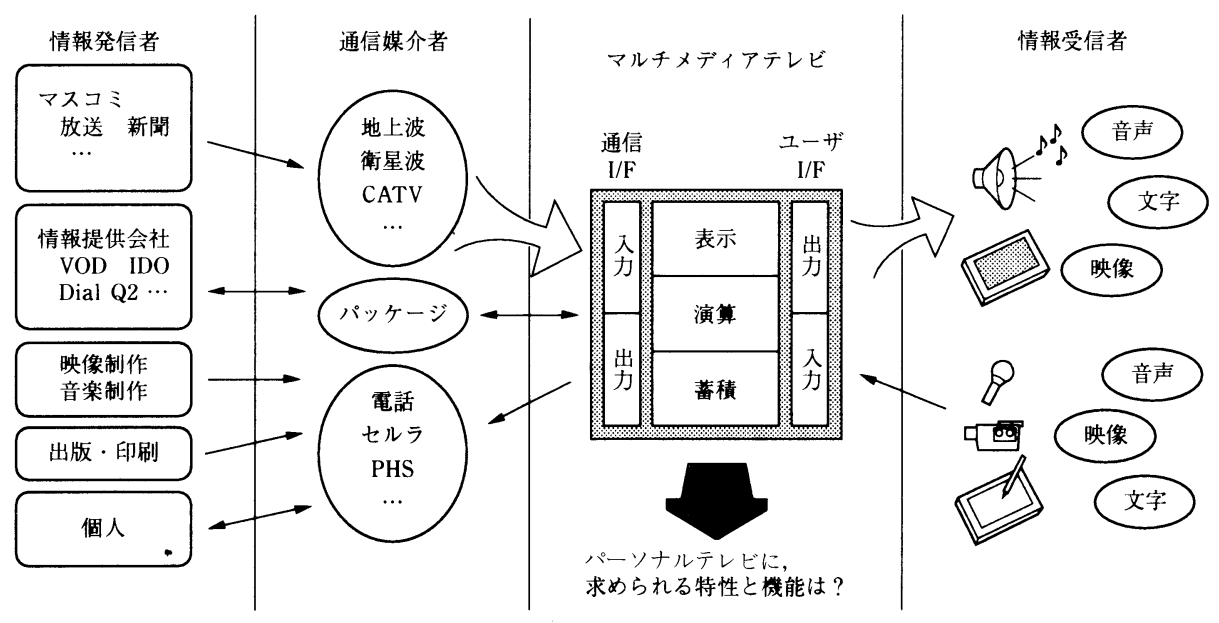

図 1 マルチメディアテレビの基本構成

表 2 パーソナルテレビに望まれる仕様

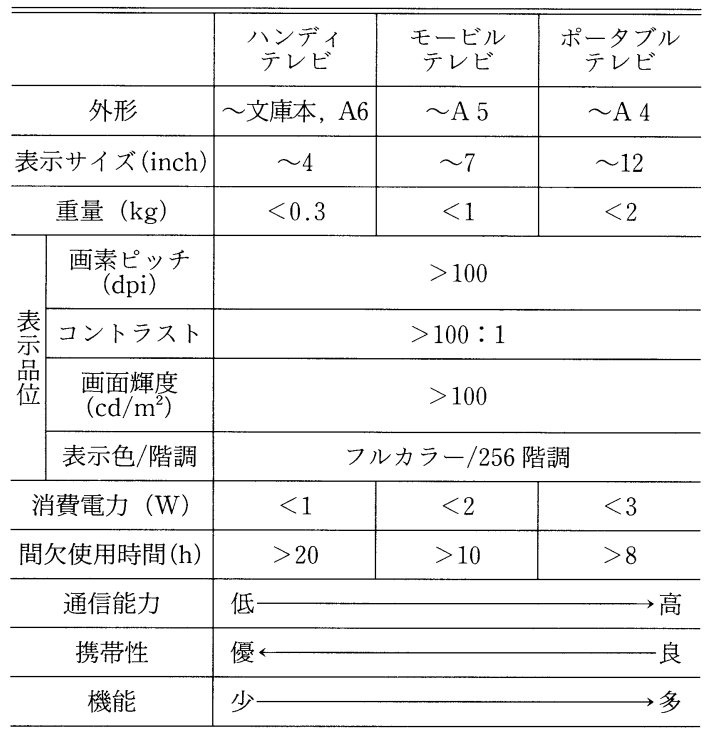

染むサイズが，モービルテレビでは車のダッシュボー ド付近に設置して邪魔にならないサイズが，また，ポ ータブルテレビでは扱いやすい雑誌程度の大きさが, それぞれ望ましいサイズである。

映像を画面近くで見る場合, 映像の画素を気にせず に見られる画素ピッチは $100 \mathrm{dpi}$ 以上 (dpi : dot per inch）が望ましい．また，屋外で見る場合を考慮する と, 外光反射防止を備えた上で, コントラストや輝度 が要求される.表現色は「テレビ」であるから，フル カラー・256 階調が必要である.

パーソナルテレビでは, リチウムイオン電池などの
充電可能なバッテリーを用いて，1 日の行動時間をカ バーする必要がある。また，使用時または非使用時に 充電もしくは電源を供給できるか否かで，その消費電 力が制約される.

通信機能はどの夕イプも備えるが，ハンディテレビ からポータブルテレビになるにしたがって高速・大容 量となる，パーソナルテレビでは，ユーザの入力情報 量が少ないのでキーボードではなく, 省スペースの夕 ッチパネルやポインティングデバイスが望ましい.

\section{4. パーソナルテレビにおけるディスプレイ}

マルチメディアにおけるパーソナルテレビを実現す るキーデバイスはディスプレイであり, 高精細のフル カラー動画像や文字を薄型, 低消費電力で表示するデ イスプレイデバイスが求められる. パーソナルディス プレイとして好適なディスプレイ技術の動向を述べ る.

\section{1 フラットパネルディスプレイ}

従来, 携帯用機器の文字表示には液晶が, 映像表示 にCRT (Cathode Ray Tube) が主に使われていたが, マルチメディアパーソナル用ディスプレイとしては, テキストと映像の両方の表示ができることが必須であ る.また, 直視型パネルとして薄型, 軽量, 低消費電 力, 耐環境性などの実用上の諸要求を満足しなければ ならない.

種々のディスプレイ技術の中で，近年の液晶ディス プレイ ${ }^{2)}$ の技術進歩と応用展開はめざましく, マルチ メディア表示デバイスとして最有力である. 本来の薄 型, 低消費電力の特徵に加えて, TFT (Thin Film Transistor）駆動法によりカラーの動画像の表示も行 
えるようになり，ノートブックパソコンのカラー化が 急速に進展している.

ポータブルユースの液晶ディスプレイの課題は, 更 なるコストの低減化と低消費電力化である，消費電力 については, バックライトの比率が大きく, ポリシリ コン TFT 駆動などによる高開口率化, 導光板など光 学系の効率改善が行われている.また, 究極的な省電 力化としてバックライトなしの反射型カラー液晶の研 究が進められている.

一方, CRT の課題であった薄型化は, 平面コール ドカソードの技術で解決できる。それが, FED(Field Emission Display) ${ }^{3)}$ である. 図 2 にるように、マ イクロチップカソードと呼ばれる微小な針の先端か ら, 電界効果によって電子が放出される, それを加速 して対向する蛍光体を励起し, 発光させる. 原理的に フルカラーの映像を省電力で表示することができる超 薄型の CRT といえる. 現在, 6インチ対角のカラー 表示が実現されている4).

\section{2 バーチャルディスプレイ}

携帯用として機器を小型化していくと, 直視型ディ スプレイでは表示が小さく見えにくい.また, 画角が

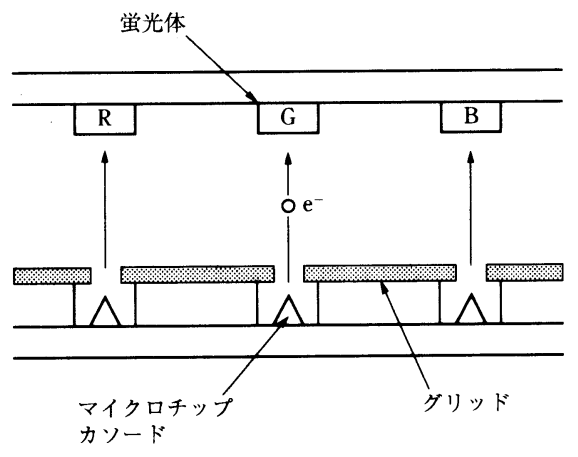

図 2 FED 断面図

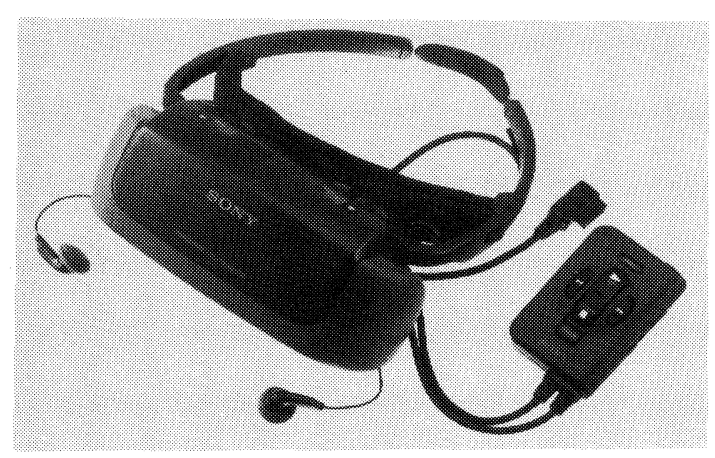

写真 1 ヘッドマウントディスプレイ
小さいとエンタテイメントとして視覚効果による感動 を与えられなくなるという本質的な問題が生ずる。こ れを解決するのが, 光学的な虚像（バーチャルイメー ジ）を見るバーチャルディスプレイである．

一例として，小型の液晶パネルを 2 枚用いた HMD (Head Mounted Display) ${ }^{5)}$ を写真 1 に示す.

HMD は小型ながら高解像度, 広画角の表示を実現 でき, 完全にパーソナルなディスプレイとして，ま た，身体の動き検出と組合せて，バーチャルリアリテ イディスプレイとして使用できるなど，新しい映像空 間を提供できる。

\section{5. 各種メディアとのコネクション}

図 3 に，マルチメディアテレビにおいて用いられる ユーザインタフェースの要素技術を示す．

パーソナルテレビのユーザインタフェースとして最 低限必要な入出力機能は, 映像・音声の入出力とそれ らを操作するための入力装置である。これに加え，必 要に応じて機能を追加するための外部機器との接続イ ンタフェースも必要である。この接続インタフェース の分野では, 赤外線を用いてコネクタの接続を不要に する $\mathrm{IrDA}^{6}$ と，映像を含めたディジタル信号を伝送 できる P 13947)の標準化が進んでいる.

表 3 には, マルチメディアテレビに用いられる通信

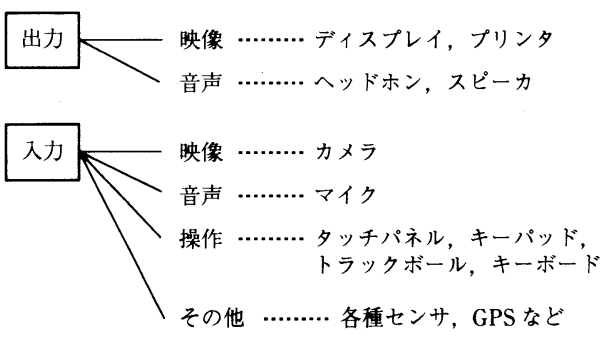

外部機器との接続 $\mathrm{I} / \mathrm{F}$

IrDA, P1394 (IEEE 1394), Audio-Video In/Out PC card (PCMCIA/JEIDA), SCSI, RS-232C

図 3 ユーザインタフェースの分類

表 3 通信インタフェースの分類

\begin{tabular}{c|c:c}
\hline \hline & 無線 & 有線 \\
\hline 広帯域 & 衛星波 & 双方向 CATV \\
$\uparrow$ & 地上波 (AM, FM, TV) & CATV \\
情報量 & 無線データ通信網 & デー夕専用回線 \\
& 衛星電話 & 電話回線 \\
狭帯域 & セルラ PHS & \\
\hline
\end{tabular}


インタフェースをまとめた．

パーソナルテレビは携帯して使用するので，「広帯 域・一方向」と「狭帯域・双方向」の無線による通信 路を組合せて使用することが一般的であろう。例え ば，地上波と PHS (Personal Handy Phone System) といった組合せが用いられる どの有線に接続するためのコネク夕も装備され, 大量 のデータ送受信に用いられる. パーソナルテレビが, 屋内外を問わず常時, 双方向通信するためのインフラ を完全に整備することは難しい．例えば，電波が届か ない場所でメッセージを入力しても，一時保存して自 動的に送信してくれるような, ユーザに負担をかけな いインタフェースの工夫も必要である.

\section{6. 近未来のパーソナルテレビは ?}

近未来のパーソナルテレビの使い方を，ある会社員 の一日の行動で物語風に表現すると……

『朝起きると, 自宅の留守番秘書となっているポ ータブルテレビに電子新聞と電子メッセージが届い ている。朝までに会社に届いたメッセージも自動転 送されている。朝食の後, 電子新聞の見出しを見 て，興味のある記事と電子メッセージをハンディテ レビに移して, 家を出る.

駅構内の案内放送を受信し，外出先までの交通状 況を確認する。電車の中ではメッセージを読みなが ら，返事を送る。一通りメッセージを読んだら， FM 放送を聞きながら気になっている電子新聞の記 事も読んでおこう。

打合せ中に撮った品物の写真に，外出先からメモ をつけて送る。メッセージが届いていないかを確 認．至急のメッセージが届いているので，見てみる とトラブル発生のようだ.すぐに電話ボタンを押し て会社に連絡する。テレビ電話機能で現在の状況を

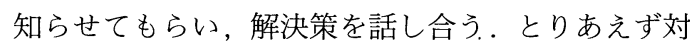
応ができて安心する。

会社へ向かう電車の中では, 車内放送チャンネル の中からスポーツダイジェストを見る。

あっという間に夕方になった．会社の端末を閉じ る。この後は急ぎのメッセージがあれば自宅に転送 される。

家に着くと, 数日前にテレショッピングで購入し たバーベキューセットが届いていた．夕食をとった 後, 明日のドライブの情報収集をする. バーチャル ディスプレイをかぶり，立体ドライブマップの鳥瞰 図から順にドライブポイントを決めていく．指定し たポイントは車のモービルテレビに転送しておく.
さて, 寝る前に, このまま映画でも見ていようか $\cdots \cdots$. I

このように，近未来には，ユーザに必要な情報の入 出力を生活のシーンごとに支援するパーソナルテレビ が期待される。

\section{7.む す び}

近未来のマルチメディアパーソナルテレビの姿を描 いてみた。「いつでも，どこでも，だれでも」マルチ メディア時代のテレビを有用に使い，そして楽しむた めには, 機器のパーソナル化と端末を有効に生かすイ ンフラの構築, 各種メディアとの接続において, 社会 的な環境が整備されることが必要である.

マルチメディアテレビが従来の AV テレビの延長 上にあるのか, コンピュータや情報機器の発展形態と して実現されるのかは興味深い. 情報の質と利便性, 対価などユーザベネフィットがなければ，マルチメデ イアテレビも世の中に受け入れられない。 また，パー ソナルテレビは携帯性の制約の下で，どこまで使い勝 手の良いハード, ソフトを提供できるかが問われ，ユ ーザインタフェースがますます重要になってくる．幅 広い技術開発により夢のあるマルチメディアテレビを 実現したいものである。

(1995 年 6 月 30 日受付)

\section{〔参 考 文 献〕}

1) Y. Hashimoto, M. Yamamoto, and T. Asaida :"Cameras and Display Systems”, Proc. IEEE, 83, 7 (July 1995)

2）日経マイクロデバイス編：“Part 8 将来技術”, フラットパ ネル・ディスプレイ 1995, pp. 199-216, 日経 BP 社（Dec. 1994)

3）横尾：“フィールドエミッションディスプレイの研究動向” O plus E, 173, pp. 82-87 (Apr. 1994)

4) J. Grand-Clément: "Field Emission Displays", 電子ディ スプレイ・フォーラム 95 講演集, pp. 82-87 (Apr. 1994)

5）川村, 芦崎, 原, 山田：”ヘッドマウンテッドディスプレイ (HMD) の開発”, 3 次元画像コンファレンス' 94 講演論文集, pp. 239-244 (July 1994)

6）三宅：“IrDA 方式の赤外線デー夕通信, 携帯型の情報機器に 標準装備へ”，日経エレクトロニクス, 628, pp. 101-110 (Feb. 13, 1995)

7）浅見ら：“特集 ポストSCSI の設計思想を探る三つの新イ ンターフェースを比較”, 日経エレクトロニクス, $612, \mathrm{pp} .125$ -163 (July 4, 1994)

8）金谷：“ディジタル移動体通信 1. 現状と動向”, テレビ誌, 49, 6, pp. 717-721 (June 1995)

9）竹中ら：“小特集 パーソナル移動通信” , 信学誌, $78,2, \mathrm{pp}$. 121-178 (Feb. 1995)

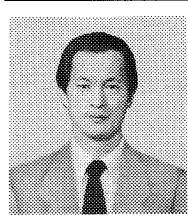

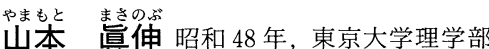
物理学科卒業. 同年, ソニー(株) に入社. CD など光ディスクの技術開発と標準化の業 務を経て，平成元年より，次世代ディスプレ イの研究開発に従事. 正会員. 